\title{
Evaluation of Coronavirus Families \& Covid-19 Proteins: Molecular Modeling Study
}

\author{
Majid Monajjemi $^{1 *}$ (D), Sara Shahriari ${ }^{2}$, Fatemeh Mollaamin ${ }^{1}$ \\ Department of Chemical Engineering, Central Tehran Branch, Islamic Azad University, Tehran, Iran \\ Department of Chemistry, Central Tehran Branch, Islamic Azad University, Tehran, Iran \\ * Correspondence: maj.monajjemi@iauctb.ac.ir;
}

Scopus Author ID 6701810683

Received: 4.04.2020; Revised: 24.04.2020; Accepted: 27.04.2020; Published: 1.05.2020

\begin{abstract}
Several Proteins, receptors, S proteins including s1 and s2 such as 6LU7, 6Q05, 4oW0, 6nur, 6Y84, $5 \mathrm{zVK}$ and $6 \mathrm{vW} 1$ were modeled and simulated via docking. All water molecules were deleted, then the covalently bound ligands were unbound from necessary places in those macromolecules including $\alpha, \beta$ double bond of the ligand, that behave as acceptors. The Structure Preparation modules of MOE were used to correct PDB inconsistencies and to assign the protonation state at biological ph. It is notable the structural knowledge of the CoV-RNA synthesis complexes was a structure of the NSP- RNA polymerase. Its structural gaps are containing information regarding the single $\mathrm{N}$-terminal extension of the virus polymerases. $\mathrm{CoV}$ is partitioned into alpha, beta, gamma and delta categories. Among them the beta group initially consists of A, B, C, and D subunits.
\end{abstract}

Keywords: Coronaviruses; CoV-RNA; SARS-CoV-2; COVID-19.

(C) 2020 by the authors. This article is an open access article distributed under the terms and conditions of the Creative Commons Attribution (CC BY) license (https://creativecommons.org/licenses/by/4.0/).

\section{Introduction}

The infection through the coronavirus (COVID19) emanated in the Wuhan city of China's Hubei Province by the end of 2019. These infections spread out to 195 countries up to now. The total numbers of confirmed COVID-19 infections are near one million, plus around half of these amount suspect cases, and the numbers of deaths are over one hundred up to now $[1,2]$. The crystal structures of the COVID-19 protease in complex with the "Peptidomimetic" inhibitors were made available recently [3,4]. Moreover, the Zhang group, developer of the popular homology-modelling [5] made available 3 dimensional structural models [6] of the COVID's proteins in the related genome.

In addition two segregate goals, the COVID-19 (6LU7), were thought-out. It is notable receptor model that can be provided using MOE2019 software [7]. Coronavirus consist of a genome include of long m-RNA strand and those genomes attack to target like a m-RNA during infect the cells, and direct the synthesis of two large polyproteins that the viruses need for replicating new viruses [8-10].

Ten, years after the SARS-corona virus, a new Coronavirus named Middle East Respiratory Syndromes (MERS) have infected human with a rate of nearly 50\%. Health Organization global or WHO cases count for MERS was reported in September 2012. The MHV or (Mouse Hepatitis Virus), which is nearly depend to SARS and MERS corona virus, have long served as a model for study of both the molecular biology of those members of these viral families. These viruses infect several of human and animal host's cells, which can be 
also, carry out their infection and replication. Also, various proteins have a major role in the replication mechanism, although those roles are poorly defined.

In these cases, there is necessary to know the definition of those proteins in terms of these mechanisms. The proteins contain a replication/transcription complexes that make more RNA, various structural proteins, and two proteases. These proteases play important roles to cut the polyproteins inside all of the functional spices. The major section protease of this virus makes most of those cuts. The SARS-CoV-2 (2019-nCoV) which is currently sparking most dangers in "Wuhan" is a dimer of the protein folding is the same as to serine proteases such as trypsin and also the cysteine amino acids $[11,12]$. The dimer has the peptides-like inhibitors bound in the active sites. Pair proteases from the SARS virus are the main proteases are similar to the Wuhan's virus, including a few splits at eleven sites in the polyproteins (Figure 1).
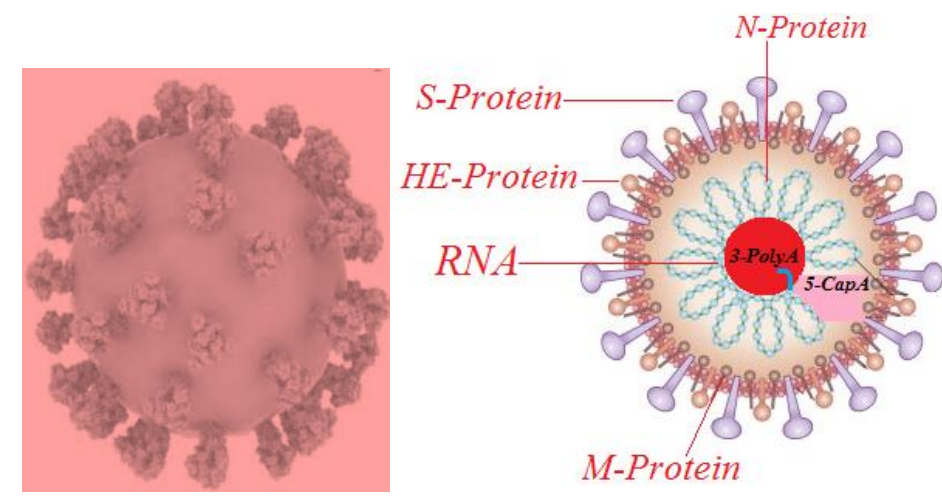

Figure 1. Wuhan's virus, including a few splits at several sites in the polyproteins of covid-19.

Coronaviruses have several categories into four conformations with different architecture and molecular structures. The proteases of those viruses are different in drug designing. Important approach is to try for designing suitable ranges of inhibitors against the bat coronavirus, which may then prepare a way to discover specific inhibitors for those type viruses. All subunits of CoV-RNA have been provided including several non-structural proteins (NSP) which produced viral polyproteins. There were several attempts for characterizing the replication complexes of $\mathrm{CoVs}$, which resulted in high-resolution structures determination for many of the SARS-CoV-NSPs using X-ray crystallography and NMR [1317]. Obviously, the structural shape of the CoV-RNA synthesis complexes were a combination of the NSP- RNA polymerase and its structural gaps are including information of the Nterminal extension from virus polymerases. Covid-19 has been developed with the unique RNA-stranded that is associated with a few natural hosts. $\alpha$ - CoVs are categorized feline F$\mathrm{CoV}$, Feline Enteric Coronavirus (FECV) and Feline Infectious Peritonitis Virus (FIPV), the porcine TGEV (or Transmissible-Gastro-Enteritis-Virus), Porcine PEDV (or EpidemicDiarrhea-Virus), Porcine Respiratory Coronavirus (PR-CoV) and the canine C-CoV. $\alpha$ - CoVs also agreement with human $\mathrm{CoVs}$ such as $\mathrm{H}-\mathrm{CoV}-229 \mathrm{E}$ and $\mathrm{H}-\mathrm{CoVNL} 63$, but various bat Coronaviruses. $\beta-\mathrm{CoV}$ also infects a wide range of mammalians, with various types such as mice, human with SARS-CoV, HCoV-OC43, HCoV-HKU1, and MERS-CoV, Murine coronavirus (MHV) and Bovine Coronavirus (B-CoV). $\gamma-\mathrm{CoVs}$ are specific of birds, with one exception of a beluga whale Coronavirus. $\delta-\mathrm{CoVs}$ were discovered in 2012 with several subunits (HKU11, HKU12, HKU13) Coronavirus from mammals to birds [18]. Among them, the beta group initially consists of A, B, C, and D subunits (scheme 1.) 

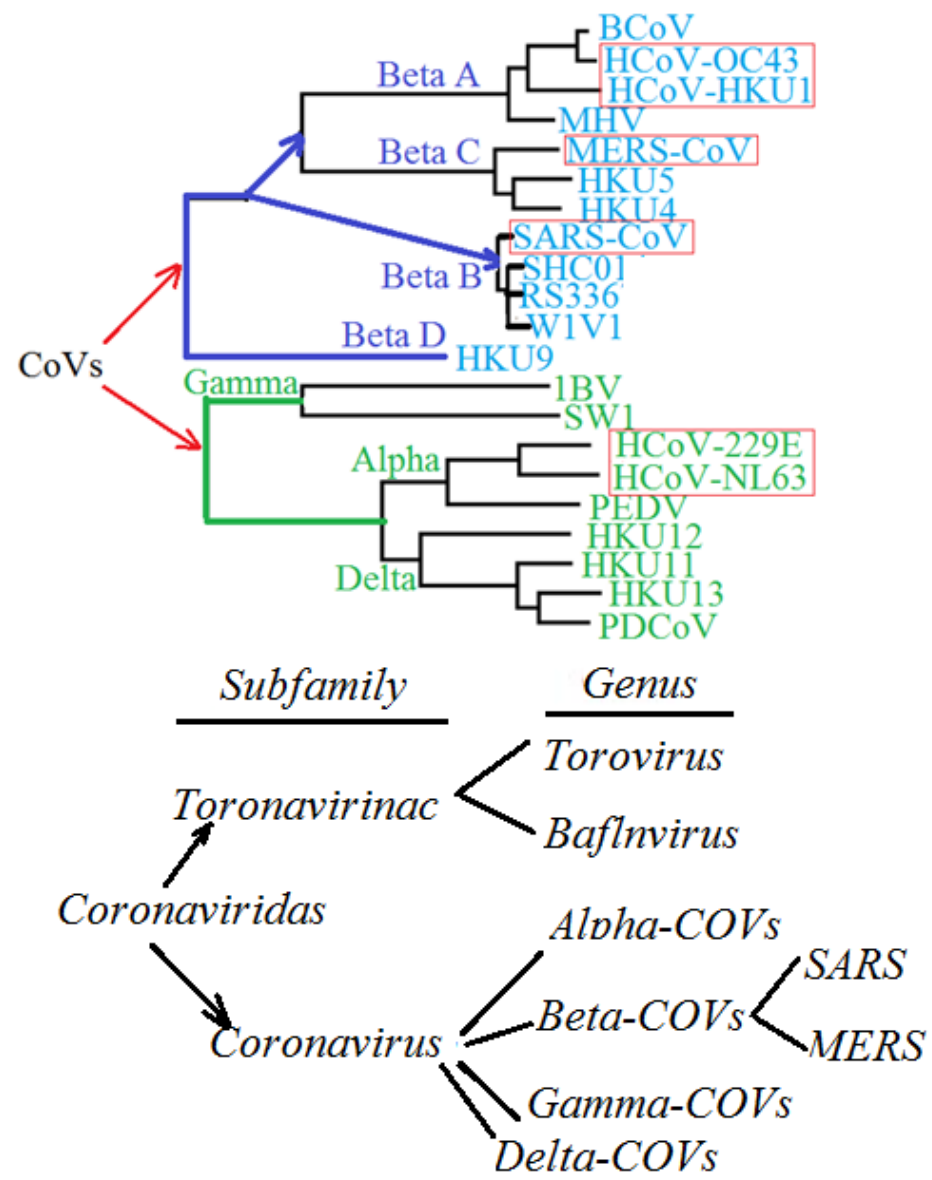

Scheme 1. Schematic trees created with the H-CoVs from all four gen- groups. H-CoVs are denoted in red rectangular frame.

These six H-CoVs are including (1)-HCoV-229E (229E) and (2)-HCoV-NL63 (NL63) in the alpha group, (3)-HCoV-OC43 (OC43), (4)-HCoV-HKU1 (HKU1) in beta subgroup A, (5)-(SARS-CoV) (severe acute respiratory syndrome) CoV in beta subgroup B, and finally (6)MERS-CoV (Middle East respiratory syndrome CoV) in beta subgroup C [9-13]. Recently, SARS-CoV and MERS-CoV have been emerged in the human population and caused severe pulmonary disease with alarmingly high case-fatality rates. SARS-CoV infections firstly emerged at China in 2002 which spread rapidly as a global epidemic. MERS-CoV emerged in Saudi Arabia in 2012 and spread via the Middle East and also in 2015 another type of MERS$\mathrm{CoV}$ appeared in South Korea. By the way, the other common viruses including 229E, OC43, and NL63, generally infect the human upper respiratory tract. In addition they also are responsible for severe and even fatal diseases in children, old people, and immunocompromised patients [18-23]. In the range of those $\mathrm{H}-\mathrm{CoVs}$, that are quickly evolving, OC43 isolates with new genomes are being continuously identified [21-23].

The SARS-like-CoV and MERS-like-CoV are great threats to human health. Recent works discovered several types of SL-CoV, as same as SL-WIV1-CoV and SL-SHC014-CoV that can be applying the same SARS-CoV receptor straightly enter permissive human cells without the need for adaptation [24 ]. SARS- became pandemic, behind disappeared during the quarantine precautions were taken as well as the ML-CoVs, are bat CoV-HKU4, were exhibited for recognizing the MERS-CoVs receptors CD-26 and infect human cells, after mutations of S746R with N762A) into its S protein [25 ]. 


\subsection{Genome structure of coronavirus.}

Coronavirus encode 5 proteins in their genomes which are known as Spike (S), Membrane (M), Envelope (E) glycoproteins, Hemagglutinin Esterase (HE) and Nucleoncapsid $(\mathrm{N})$ protein, (Figure 2). It is thought the virus particles are huddled together owing to interaction between those proteins $[26,27]$

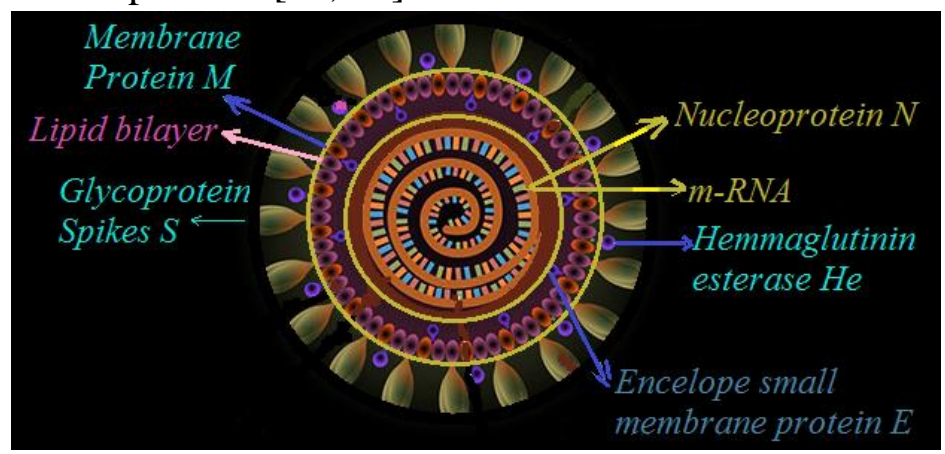

Figure 2. Structure details of covid-19.

S-Glycoproteins are placed in external layer of virus and give a typical shape and also form homo-trimers that allow the model of sun-like morphology due to the name of Coronavirus $[28,29]$. S proteins bind to the membrane through $\mathrm{C}$-terminal area interact to $\mathrm{M}$ proteins where can be bound to the specific surfaces receptors inside the plasma of the host cell by the $\mathrm{N}$-terminus of that $\mathrm{S}$ protein [30]. M Glycoprotein has 3 transmembrane sections and is glycosylated in the Golgi apparatus. The modifications of the M proteins are crucial for the virus to fuse inside the cell for making protein antigenic [31]. The M protein is an important key for regenerating virions in the cells. N protein makes a complex via binding to genomics' RNA but M protein triggers the formation of related interacting virions in those endoplasmic reticulum-Golgi apparatus intermediate compartment (ERGIC) with this complex. E Glycoprotein is small protein which is composed of around 75 to 110 amino acids. About 35 amino acids in the N-terminus of the E proteins allow attachment to the membrane of viruses. Moreover, coronavirus E protein causes a critical function in the assembly and morphogenesis of virions within the cell. In a research exhibited that the coronavirus $\mathrm{E}$ and $\mathrm{M}$ proteins were expressed together via mammalian expression for forming virus-like structures within the cell [32]. $\mathrm{N}$ protein is phosphoproteins which are capable of binding to a helix structure of viral genomic RNA and plays important role in virion structure, replication and transcription of covid-19, due to localization in replication/ transcriptional area of the covid-19 and the ERGIC area.

\subsection{Mechanism of replication and translation corona-virus into the cell.}

The replication appears in host cell cytoplasm which during this process the virus initially binds to the receptor on the cell surfaces through the spike (S) protein. When S proteins are attached to those receptors, the conformational structures appear in the structure and the process of entry into the virus cell begins. The process with endocytosis is dependent on $\mathrm{pH}$ via the receptor [33-36]. During entering virus in the cytoplasm, the component of virus releases the RNA genome which is a single-stranded, non-segmented RNA virus with the largest known RNA genome (gRNA) (Scheme2\&3) [33-36]. 


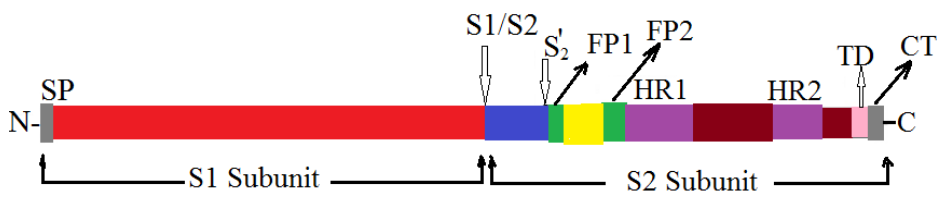

Scheme 2. Schematic linear representation of the coronavirus $\mathrm{S}$ protein with relevant domains/sites indicated: signal peptide (SP), two proteolytic cleavage sites (S1/S2 and $\mathrm{S}_{2}{ }_{2}$ ), two proposed fusion peptides (FP1 and FP2), two heptad repeat regions (HR1 and HR2), transmembrane domain

(TD), and cytoplasmic tail (CT).

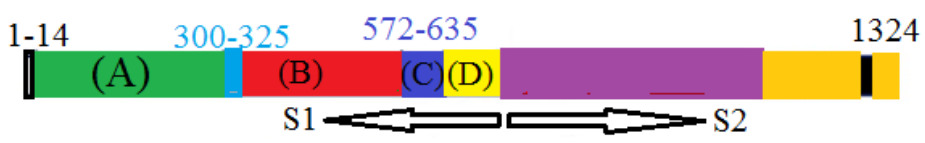

Scheme 3. Schematic representation of MHV spike protein sequence, the S1 domains A, B, C, and D, are colored in green, red, blue and yellow respectively, and the linker region connecting domains $\mathrm{A}$ and $\mathrm{B}$ in turquoise, the $\mathrm{S} 2$ region is colored in violet.

Their genome contains of 7 genes which are organized into 5'non-structural protein coding area (gene 1) and also are two-thirds of the genome, and 3' structural (Fig.1) and nonfundamental proteins coding comprising the gene [37]. The replicas gene 1 product is encoded the large frames. After synthesizes of those proteins, contain 16 units, non-structural protein where these 16 proteins form Double-Membrane Vesicles (DMV). As well as simultaneity, these DMV are virus Replication and Transcription Complex (RTC) [38, 39]. Genes 2 to 7 are translated via sub-genomic m-RNA and Sub-genomics RNAs encode the main viral structural proteins-S, Envelope protein-E, membrane protein-M, Nucleon-capsid protein-N and the accessory proteins, which are essential for virus-cell-receptor binding. The newly structural synthesized protein is released into the endoplasmic reticulum. All of these proteins, along with the N-protein, are linked to the viral genomic RNA and localized in the ERGIC area [40] (Figure 3). Although, N proteins are known for coronavirus replication, the specific plays that these proteins act in these processes remain unknown. But, many researchers predicate that $\mathrm{N}$ protein interaction with nsp3 plays a critical role in the virus replication early in infection. Therefore, the next section yields detail information about determination of structure $\mathrm{N}$ and interaction mechanism of $\mathrm{N}$ protein and $\mathrm{nsp} 3$ proteins.

Therefore, it is needed for determining structure of $\mathrm{N}$ for understanding the replication and transcription mechanisms. Therefore, these sections yield some information about the structure and function of MHV-N proteins. The MHV-N proteins include two structurally separated RNA binding domains that are called N-terminal domain or NTD and C-terminal or CTD dimerization domain linked. The NTD domain is known as it plays an important role in $\mathrm{CoV}$, both in viral replication and transcription [41].

As an instance, NMR chemical shifts perturbation approaches [42] reveal that the regions of the SR-rich and NTD in MHV N protein interact with MHV nsp3 as well as there were suitable correlations among the $\mathrm{N}$-nsp3 interaction and their abilities of $\mathrm{N}$ protein for stimulate the infectivity of MHV gRNA.

These data confirm the critical situation of $\mathrm{N}$ and nsp3 interaction and prepare any further help to its proposed function in initiation of coronavirus infection. Nicolas, et al. [43] exhibited 3D structure of NTD-MHV-N protein via applying X-ray method. This matter consists of only NTD domain but unfortunately, N-nsp3 interaction in the virus replication acts an important function in 3D structure of the SR-rich area. 


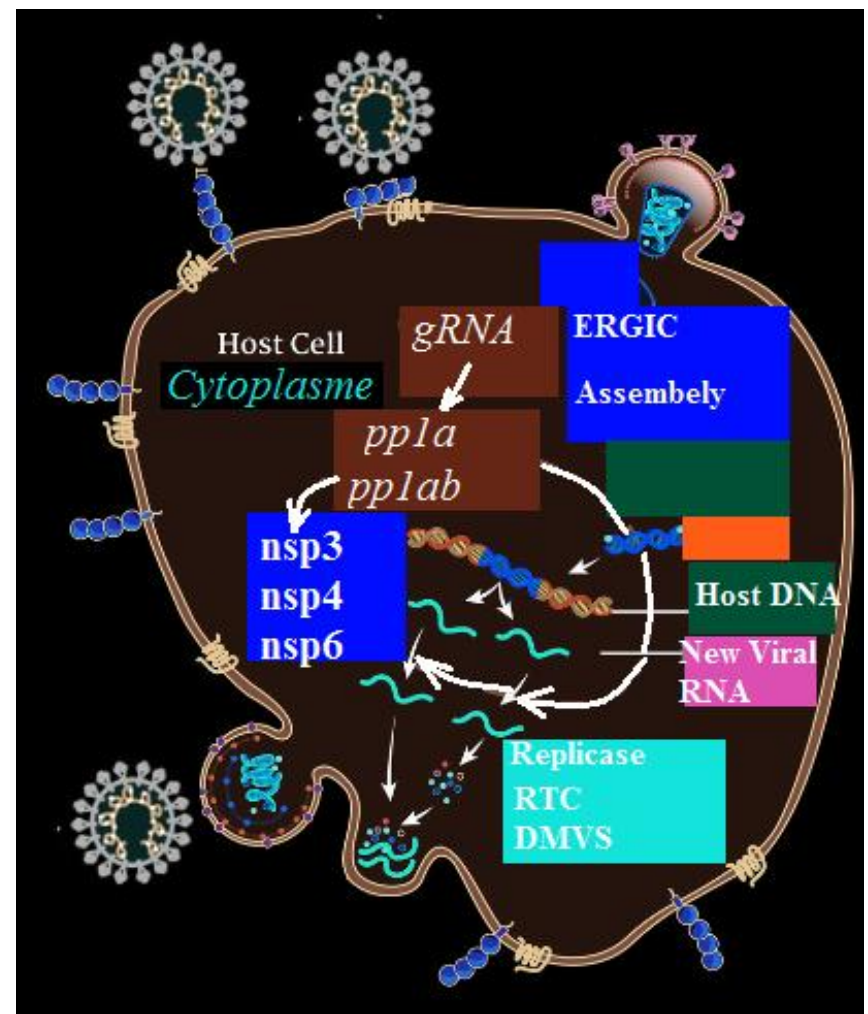

Figure 3. Details and mechanism of coronavirus in cell.

\subsection{Structure of the coronavirus S protein and S1, S2 subunits.}

"S" protein is a viral fusion proteins [44] similar influenza [45-47] that same as other class-I proteins could be fold with a meta-stable pre-fusion towards its translation. S protein varies among corona viruses in the area between 1150 - 1650 residues, around 225 kilo Dalton. Trimers of the "S" protein include of 17-24-nm length, club-shaped spike which design the membrane surfaces of the coronaviruses. This protein is also the main target for neutralizing antibody evoked via the immune sections of the infected hosts [48] and can be divided into two functionally distinct units. "S1 "subunit contains of receptor recognition, while the S2 unit simplifies the membrane fusion for controlling the $\mathrm{S}$ protein into the viral membrane (Figure 4).

S1, S2 subunits can be separated through cleavage splits which are known through Furin-like proteases when "S" protein bio-genesis in the infected cell. Structures of the spike subunits of two $\beta$-corona-viruses including MHV and $\mathrm{HCoV}$-HKU1 has provided novel insights into the architecture of the $\mathrm{S}$ trimer in its pre-fusion state $[49,50]$.

\subsubsection{Structure of $\mathrm{S} 1$.}

S1 protein plays a multi architecture which structurally formed to a few (4) distinguished subunits including A, B, C and D (Fig.5). That A and B might serve as a RBD. The core section of subunit "A" plays a galectin-like $\beta$ - folding, while section $B$ consist of a structurally conserved section unit of non-parallel $\beta$-sheets $[51,52]$. Unit B is also structured by an extra loop on the viral membrane direction that might place considerably in range among virus of the $\beta$-coronavirus genus dependent on hyper-variable ranges. Oligomerization of the "S" proteins yields in a nearest trimer cluster of the B subunits of the spike over top of the $S 2$, and also "A" s unit can be ordered distally of the central section. Unlike to subunits "A" and 
"B: the S1 C-terminal units "C" and "D" make up of dis-continuous units of those protein sequences contain several $\beta$-sheet configurations. Contrast to the S2 unit, S1 subunit shown a small level of conversation between various of CoVs generation. Moreover, S1 domain differs tightly in sequences spectrum from 545 (S of bronchitis viruses) to 945 residues, in other words a variety in architecture of the spikes in CoVs generation. Structural understanding of the spikes $\gamma$ and $\delta \mathrm{CoVs}$ are currently lacking. Unique folding subunits have been assigned in the S1 subunit of $\alpha$-CoVs spikes which potentially can interact with host molecules. Structural data are available for the S1 C-terminal of two $\alpha$-coronaviruses and $\mathrm{S}$ proteins which differ considerably from which of $\beta$-CoVs. $\alpha$ - CoVs exhibits a $\beta$-sandwich core conformation, while a $\beta$-sheet core structures are seen for $\beta$-CoVs [53].

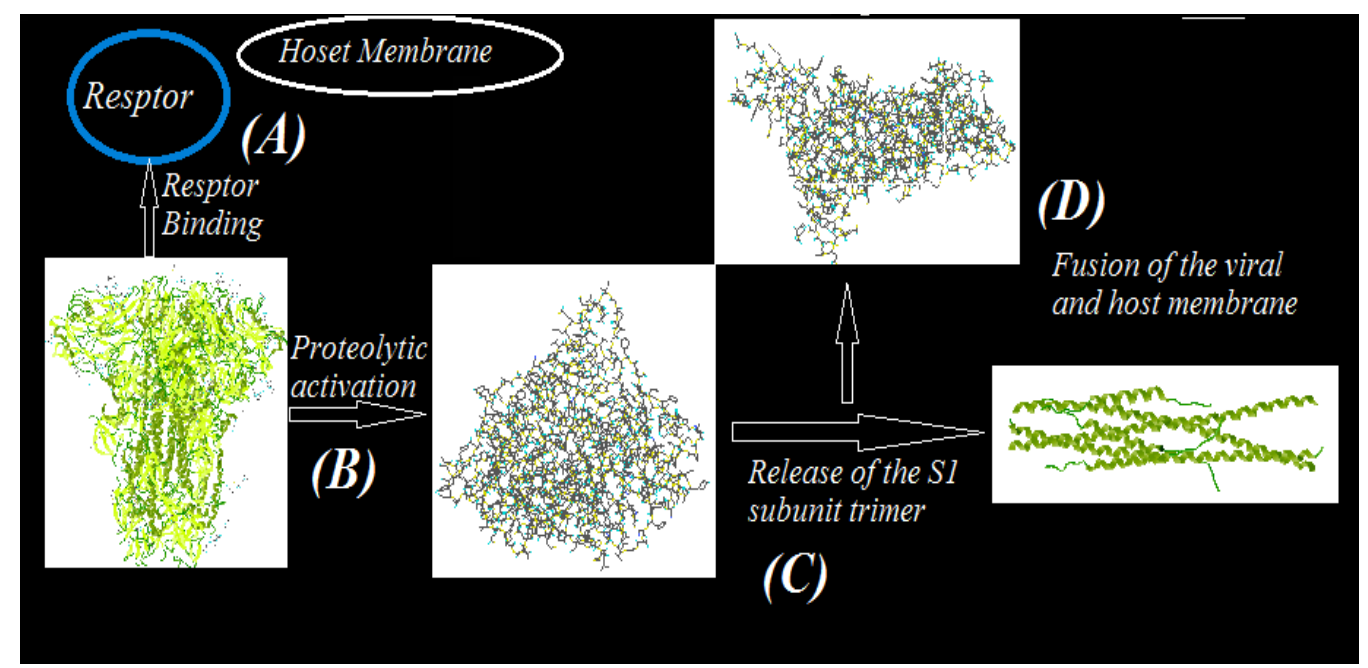

Figure 4. Tectonic conformational changes of a coronavirus spike.

\subsubsection{Structure of $\mathrm{S} 2$.}

The S2 unit contains key protein sections that simplify virus-cell fusion and also consist of fusion peptides with two heptad repeat ranges (HR1 and HR2). In the MHV and HKU1 S proteins, the $\mathrm{S} 2$ unit consists of multiple $\alpha$-helical configuration and non-parallel beta-sheets at the viral membrane proximal end.

75 angstrom of length central helical configuration of the HR1 zoon stretches over the entire length of the S2 trimer. The HR1 folding in the length of the S2 domains, this long alphahelix structure through this region in post-fusion structures [54-56]. 55 angstrom of long helical S20 cleavage site runs parallel to central helix with hydrophobic interactions. The fusion peptide configuration of a small helix segments is buried in the interfaces via the other elements of S2. In contrast classes, one (I) fusion proteins, those conserved fusion peptides (FP1) are not straightly upstream of HR1 because of residues up-stream of this spectrum. Recently a report showed the experimental confirmation for the existence of another fusion peptide (FP2) of the HR1 region [57]. This HR2 placed near the C-terminal end of the S unit, therefore, their prefusion configurations remain unknown yet.

The distal tip of the $\mathrm{S} 2$ trimer connects through a hydrophobic interaction with domain $\mathrm{B}$ and consists of the C-terminal region of HR1 [58, 59]. Interactions among these spectrums of the S2 trimer and unit B might therefore prevent premature structural change due to the conversion of the initial fusion " $\mathrm{S}$ " protein towards the stable past fusion configurations. Also, 
subunits $\mathrm{C}$ and $\mathrm{D}$ of the $\beta$-CoVs S1 domain and connect to subunits $\mathrm{A}$ and $\mathrm{B}$ via surfaces of the adjacent S2. Domain A seems to play in this respect due to its interaction with the S2 trimer.

\section{Materials and Methods}

The interaction of several inhibitors has been accomplished via docking and modeling simulation. In docking the Vina [60], those receptors were processed via Auto dock software, while the number of water molecules has been deleted and polarity of hydrogens and charges have been added in the simulation. A few amino acids same as His have been protonated in the neutral structure compared with crystal data. This model was chosen for testing the binding affinities of several natural products on beta-CoVs (SARS-CoV) and alpha (MERS-CoV) that are a fundamental virus with an initial mutation of COVID-19. Sars-Cov2 (COVID-19) has several basic proteins for making its infection and growth in host cells, such as protease and spike glycoproteins. The RBD of spike (RBD-S) could be bind to the ACE2 at PD of the host cells (Figure 4), leading to the viral infections. In this study, COVID-19 sub molecules have been compared to SARS-CoV-2 theoretically and experimentally. Computational calculations have been used both by Linux and Windows 10 operating systems. 2019-nCoV receptorbinding domain complexed have been modeled with its receptor of human ACE2 of PDB ID 6VW1 and COVID-19 main protease with un-landed active site (2019-nCoV, coronavirus disease 2019, SARS-CoV2) of PDB 6Y84 [61] (Figure 5).

5ZVK Crystal Structure of the human Coronavirus MERS HR1 motif in complex with pan-CoVs inhibitor EK1 [62] .The PDB ID 6VW1 was used as the model of PD-ACE2 in complexes with RBD of covid-19. The structure of all chemical components was extracted from drawn in Chem-draw, Chem-office and Hyper-chem software. Conformational search and energy minimization in Charmm with OPLS force fields have also been used.

\subsection{Docking simulation.}

The docking simulation arranging is also applied triangle matcher as the score function of setting methods. Several force fields same as Amber, MM+ and BIO+ were applied to OPLS for refining the docking results. Data of docking explained the affinity represented and binding interaction of each compound on the protein goals.

ACE2 in human is enzymes which have an effect on blood pressure. In COVID-19 families, ACE2 are receptors, an entranceway, in the airways, alveolus and in blood vessel linings. ACE2 families are also receptors for $\beta-\mathrm{CoV}$ and NL63-CoV. Obviously, MERS-CoV $(\alpha-\mathrm{CoVs})$ show a different receptor compared to other viruses. Method for developing vaccines and treatment is a 3-D structure of the parts of the virus that contact human cells. SARS and NL63-CoV attached to a helical section of ACE2 and bind with cell membranes through tunnels and bridges to comprise a "hot spot" for viruses.

The viral hot spot where beckons both SARS and COVID-19 are shared drug and vaccine target and so all the work on developing the SARS vaccines are currently in the spotlight. Scientist from the S1 parts of the viral spikes hugs the ACE2 receptor at the area of five amino acids to blocks the proteins synthesize. Even though 5 or 4 amino acids differ in COVID-19, they are the same as in size and charges to their counterparts in SARS. It is notable which $\mathrm{S} 1$ attaches SARS to the ACE2 receptors with docking. 

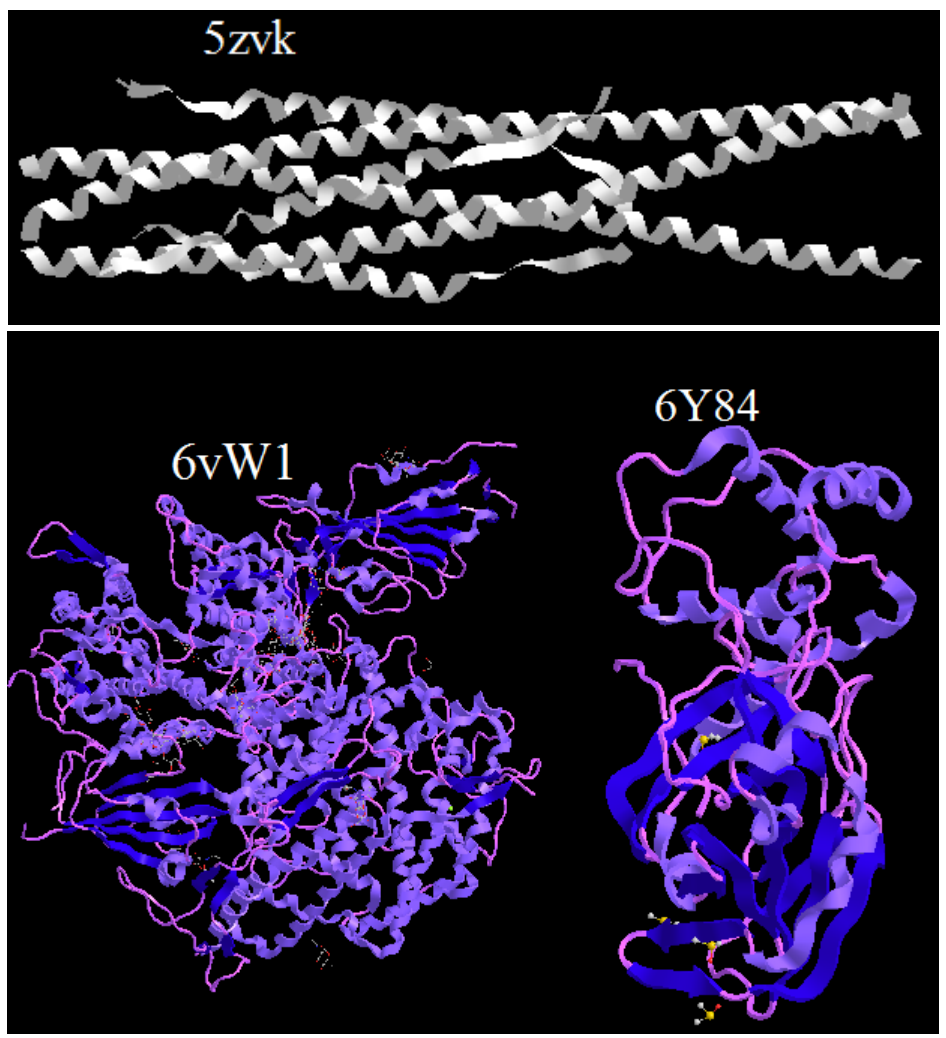

Figure 5. ACE2 of PDB ID 6VW1and COVID-19 main protease of PDB 6Y84 and 5zvk.

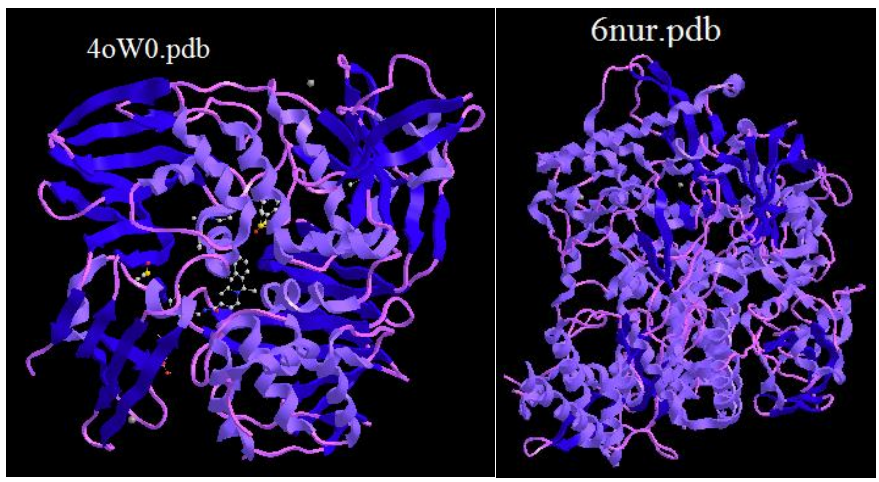

Figure 6. Structure of the SARS-CoV nsp12 polymerase bound to nsp7 and nsp8 co-factors and X-ray structural and biological evaluation of a series of potent and highly selective inhibitors of human coronavirus papain-like proteases.

Obviously the new virus "poses a significant public health risk for human transmission through the S-protein-ACE2 binding pathway." The CoVs covering has been accomplished via (E) proteins that are small, integrals protein including several aspects of the viruses' life cycles, such as assembling, enveloping, and formation. Although E proteins are the smallest of the main structural proteins, the most important and enigmatic in view point of any reaction details. During the replication cycle, $\mathrm{E}$ is translated much more numerous inside the infected cell. 6NUR is a protein data bank related to the SARS-Coronavirus NSP12 bound to NSP7 and NSP8 co-factors [63] and X-Ray Structural and Biological Evaluation of a Series of Potent and Highly Selective Inhibitors of Human Coronavirus Papain-Like Proteases (Figures 6 \&7) [64].

Based on our previous methods and experience of biology information and macro molecular systems we simulated our model theoretically [65-120]. In this work, Auto dock Tools and also iGEMDOCK software has been used and via this method, the suitable receptors 
can be selected for the binding site in whole COVID-19 protein structures. The protein macromolecules are worked by a ligand, and iGEMDOCK can help rapidly define the appropriate binding sites. The following items have been done in docking simulation :( a), Preparing Binding Sites on the Protein Ligands. (b) Browsing and selecting the protein files. (c) Defining the binding sites kind as the bounded ligands. (d) Designing a center for the binding sites through selected ligands. (e) Setting arranging the size of the binding sites by the extended radiuses from the selected ligands.

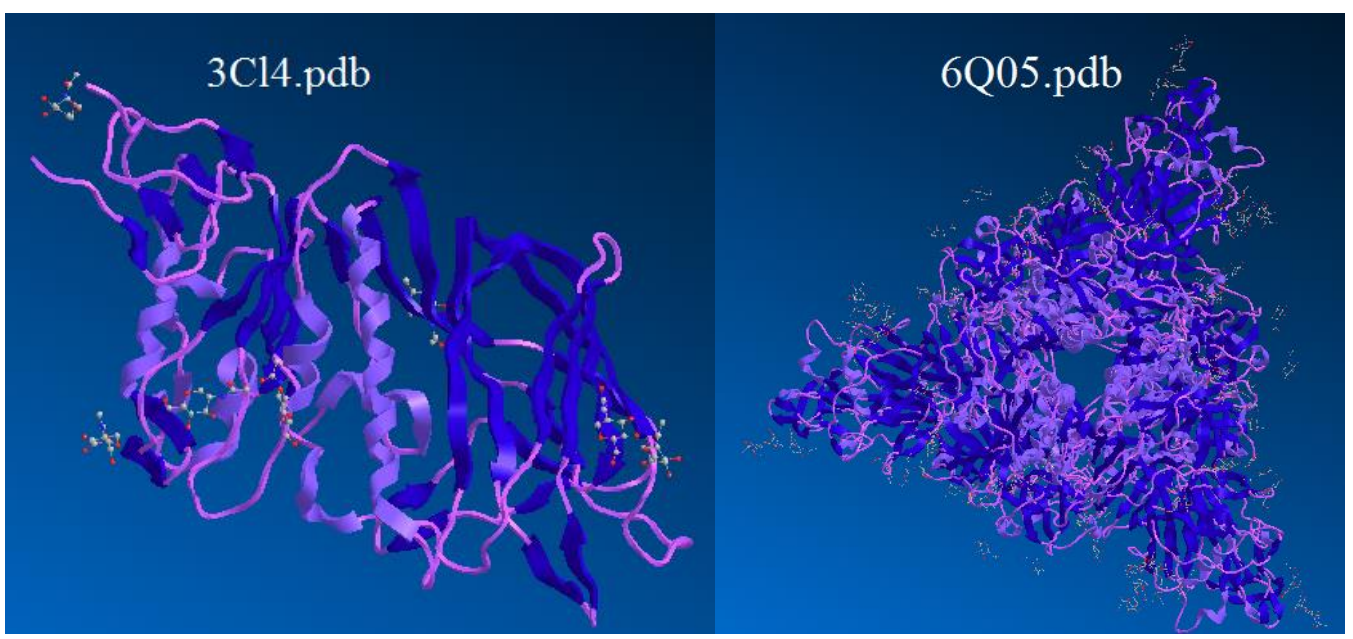

Figure 7. Crystal structure of bovine coronavirus hemagglutinin-esterase and MERS-CoV S structure in complex with Sialyl- Lewis X https://doi.org/10.2210/pdb3CL4/pdb; https://doi.org/10.2210/pdb6Q05/pdb;

IGEMDOCK produces and predicts the analysis surrounding by visualized tool and post analysis tool for researcher that can visualize the docked states, and categories through the protein-ligand interactions. Obviously, the prediction and scores of ligands can be saved in the output path. The minimum energies pose of each ligand will be outputted into the location of "best: Pose". These analysis tools are premeditated based on the analysis of those poses. Trough looking for the bounded structures of some ligands, they could be select via the check box of ligand. If the co-crystallized substrate ligands are reflexed on the binding site structures, it will be predicted poses. Clusters situation and also their analyzing are the partitioning of the data sets into sub-sets. These data in each ideally sub-set would share some general trait. Interactions data are extracted from the protein-ligand binding and atomic compositions are also accounted for atomic types in different functional groups. You are able to specify the number of clusters for these data or adjust the number by the preliminary clustered results. Cluster estimation is the analysis of a data ranges into subsets and the information in each subset can be sharing some general properties. These are based on interaction and atomic combination aspects. Interaction aspects are extracted from the protein-ligand couples and atomic combinations are calculated atomic types in several functional groups. In the past five years, molecular modeling on the corona viruses of "S" have been simulated both N-terminal and C-terminal area. S1 potentially, can bind to host receptors as RBDs [122-124]. $\beta$ - CoVs can be to attach proteinaceous receptor exclusively. The alpha structure 229-E, serotype II feline $\mathrm{CoV}$ "F-CoV", and porcine respiratory CoVs apply the human amino-peptidase of its host as receptor $[123,124]$. The alpha form and also $\beta-\mathrm{CoV}$ or SARS-CoV both apply "ACE2" (Angiotensin converting enzyme 2) as a functional receptor [124], while the beta form and MERS-corona virus recruit "DPP4" (dipeptidyl peptidase-4) as a receptor [125, 126]. RBMs 
mean "receptor-binding motifs" which in the S1 CTRs of $\alpha$-CoVs and $\beta-\mathrm{CoV}$ spikes are demonstrated over a few loops from $\beta$-sheets structures [103, 104]. $\alpha$ - CoVs and $\beta$ - CoV determines receptor specificity that might be varying extensively due to a similar core structure and common evolutionary origin. The identical positions are appearing for the CTRs of betaCoVs SARS-CoV and alpha or MERS-CoV which bind ACE2 and DPP4, respectively [125127]. In other hand, the CTRs of the alpha-Corona virus and H-CoV-NL-63 and beta-Corona virus SARS-CoV all recognize ACE2, through distinct molecular interactions [128-133].

\section{Results and Discussion}

Several Proteins, receptors, S proteins including s1 and s2 such as 6LU7, 6Q05, 4oW0, 6nur, 6Y84, 5zVK and 6vW1 were modeled and simulated via docking. All water molecules were deleted, then the covalently bound ligands were unbound from necessary places in those macromolecules including $\alpha, \beta$ double bond of the ligand, that behave as an acceptor. The Structure Preparation modules of MOE were used to correct PDB inconsistencies and to assign the protonation state at biological $\mathrm{pH}$.

The default Charmm and Amber10EHT force-fields, coupled to the Born solvation model were assigned into of these systems. These ligands were then minimized, keeping the receptors constrained. After this step, receptors were optimized via applying backbones and keeping the ligands constrained. In the end, the complexes were minimized in two divided steps, (1) through keeping backbone restraints, (2) through removing all restraints. These receptors and those ligands were then saved for future use. The crystal structures of SARS$\mathrm{CoV}$ proteinase, which are a close homologue of COVID-19 proteinase, in complexes with Carboxyl-amide inhibitors were also used as reference. These systems were prepared for calculation as follows. (1) The PDB was corrected and protonated at biological $\mathrm{pH}$ using MOE as stated above. (2) The ligands were minimized, keeping the receptors constrained, using the MMFF94x force fields coupled with the Born solvation model.

The receptors were then optimized, keeping the ligand constrained, using Amber10EHT+Born. In the end, the complexes were minimized in two steps; the resulting structure was used for docking. The core CoV S Proteins structures of the CTRs in both $\alpha$ $\mathrm{CoVs}$ and $\beta-\mathrm{CoV}$ prepare a scaffold from an extended loop(s), that might accommodate the receptor switching via exchange of the RBMs. The "NTR" of the alpha corona virus and gamma corona virus $\mathrm{S}$ proteins bind to sialic acids, while the NTR of $\beta$ - $\mathrm{CoV}$ concluding B$\mathrm{CoV}$ and $\mathrm{H}-\mathrm{CoVOC} 43$ were exhibited for binding to O-acetylated sialic acids [106,107]. Only the NTR of subunit A is known for interacting with the protein receptors, being mCEACAM1a, while lacking any detectable sialic acid binding activity [108].

The NTR (MHV) exhibits a $\beta$-sandwich folding with the family of sugar-binding proteins that probably have evolved from sugar-binding domains. The RBDs in different subunits of the S proteins which can bind either proteinaceous or glycan receptors illustrates functional modularity of these glycoproteins at different subunits that might fulfill the role of binding to cellular attachment. The coronavirus $S$ proteins are thought to have evolved from the basic structure receptor recognition which was confined to the CTR within S1. The observed deletions of the NTR in some CoV species in nature are indicative of a less stringent requirement and integration of this domain with other regions of the spike trimer compared to the more C-terminally located domains of S1 and supports a scenario in which the NTR has 
been acquired at a later time point in CoV evolutionary history. Acquisition of glycan-binding domains and fusion thereof to the ancestral $\mathrm{S}$ protein may have resulted in a great extension of $\mathrm{CoV}$ host range and may have caused an increase in $\mathrm{CoV}$ diversity.

\section{Conclusions}

The most efficient of the NTR and CTR for binding to glycan or protein receptors might be related to their arrangement in the $S$ protein trimer. In contrast to the CTR, which is located in the center of the S trimer, the NTR is more distally oriented. Although protein-glycan interactions usually have low affinity, the more distal orientation of subunit A might be permitted multivalent receptors interactions, thereby increasing avidity. Interestingly, some corona viruses have been seen as the dual receptors which can bind via their NTR and CTR to glycan and protein receptors, respectively. The RBDs in different subunits of the S proteins which can bind either proteinaceous or glycan receptors illustrates functional modularity of these glycoproteins at different subunits that might fulfill the role of binding to cellular attachment. The coronavirus $\mathrm{S}$ proteins are thought to have evolved from the basic structure receptor recognition which was confined to the CTR within S1.

\section{Funding}

This research received no external funding.

\section{Acknowledgments}

The author thanks the Islamic Azad university, for providing the software and computer equipment.

\section{Conflicts of Interest}

The authors declare no conflict of interest.

\section{References}

1. Cui, J.; Li, F.; Shi, Z.L. Origin and evolution of pathogenic coronaviruses. Nat. Rev. Microbiol. 2019, 17, 181-192, https://doi.org/10.1038/s41579-018-0118-9.

2. WHO Situation Report -23, February 12th 2020.

3. Corman, V.M.; Landt, O.; Kaiser, M.; Molenkamp, R.; Meijer, A.; Chu, D.K.; Bleicker, T.; Brünink, S.; Schneider, J.; Schmidt, M.L.; Mulders, D.G.; Haagmans, B.L.; van der Veer, B.; van den Brink, S.; Wijsman, L.; Goderski, G.; Romette, J.-L.; Ellis, J.; Zambon, M.; Peiris, M.; Goossens, H.; Reusken, C.; Koopmans, M.P.; Drosten, C. Detection of 2019 novel coronavirus (2019-nCoV) by real-time RT-PCR. Euro Surveill 2020, 25, https://doi.org/10.2807/1560-7917.ES.2020.25.3.2000045.

4. Liu, X.; Zhang, B.; Jin, Z.; Yang, H.; Rao, Z.; The crystal structure of 2019-nCoV main protease in complex with an inhibitor N3. To be published. PDB code 6LU7 2019, http://dx.doi.org/10.1038/s41586-020-2223-y.

5. Roy, A.; Kucukural, A.; Zhang, Y. I-TASSER: a unified platform for automated protein structure and function prediction. Nature Protocols 2010, 5, 725-738, https://doi.org/10.1038/nprot.2010.5.

6. Zhang, C.; Zheng, W.; Huang, X.; Bell, E.W.; Zhou, X.; Zhang, Y. Protein Structure and Sequence Reanalysis of 2019-nCoV Genome Refutes Snakes as Its Intermediate Host and the Unique Similarity between Its Spike Protein Insertions and HIV-1. Journal of Proteome Research 2020, 19, 1351-1360, https://doi.org/10.1021/acs.jproteome.0c00129.

7. Molecular Operating Environment (MOE), 2019.01; Chemical Computing Group ULC, 1010 Sherbrooke St. West, Suite \#910, Montreal, QC, Canada, H3A 2R7, 2019.

8. John, S.E.; Tomar, S.; Stauffer, S.R.; Mesecar, A.D. Targeting zoonotic viruses: Structure-based inhibition of the 3C-like protease from bat coronavirus HKU4-The likely reservoir host to the human coronavirus that 
causes Middle East Respiratory Syndrome (MERS). Bioorg. Med. Chem. 2015, 23, 6036-6048, https://doi.org/10.1016/j.bmc.2015.06.039.

9. Santos, Y.M.; Barraza, S.J.; Wilson, M.W.; Agius, M.P.; Mielech, A.M.; Davis, N.M.; Baker, S.C.; Larsen, S.D.; Mesecar, A.D. X-ray Structural and Biological Evaluation of a Series of Potent and Highly Selective Inhibitors of Human Coronavirus Papain-like Proteases. J.Med.Chem. 2014, 57, 2393-2412, https://doi.org/10.1021/jm401712t.

10. Hilgenfeld, R.; From SARS to MERS: crystallographic studies on coronaviral proteases enable antiviral drug design. FEBS J. 2014, 281,4085-4096, https://doi.org/10.1111/febs.12936.

11. Sevajol, M.; Subissi, L.; Decroly, E.; Canard, B.; Imbert, I. Insights into RNA synthesis, capping, and proofreading mechanisms of SARS-coronavirus. Virus Res. 2014, 194, 90-99, https://doi.org/10.1016/j.virusres.2014.10.008.

12. Lehmann, K.C.; Gulyaeva, A.; Zevenhoven-Dobbe, J.C.; Janssen, G.M.; Ruben, M.; Overkleeft, H.S.; van Veelen, P.A.; Samborskiy, D.V.; Kravchenko, A.A.; Leontovich, A.M.; Sidorov, I.A.; Snijder, E.J.; Posthuma, C.C.; Gorbalenya, A.E. Discovery of an essential nucleotidylating activity associated with a newly delineated conserved domain in the RNA polymerase-containing protein of all nidoviruses. Nucleic Acids Res 2015, 43, 8416-8434, https://doi.org/10.1093/nar/gkv838.

13. Peersen, O.B. Picornaviral polymerase structure, function, and fidelity modulation. Virus Res. 2017, 234, 420, https://doi.org/10.1016/j.virusres.2017.01.026.

14. Báez-Santos, Y.M.; Barraza, S.J.; Wilson, M.W.; Agius, M.P.; Mielech, A.M.; Davis, N.M.; Baker, S.C.; Larsen, S.D.; Mesecar, A.D. X-ray Structural and Biological Evaluation of a Series of Potent and Highly Selective Inhibitors of Human Coronavirus Papain-like Proteases. Journal of Medicinal Chemistry 2014, 57, 2393-2412, http://dx.doi.org/10.1021/jm401712t.

15. Woo, P.C.Y.; Lau, S.K.P.; Lam, C.S.F.; Lau, C.C.Y.; Tsang, A.K.L.; Lau, J.H.N.; Bai, R.; Teng, J.L.L.; Tsang, C.C.C.; Wang, M.; Zheng, B.-J.; Chan, K.-H.; Yuen, K.-Y. Discovery of seven novel Mammalian and avian coronaviruses in the genus deltacoronavirus supports bat coronaviruses as the gene source of alphacoronavirus and betacoronavirus and avian coronaviruses as the gene source of gammacoronavirus and deltacoronavirus. J Virol 2012, 86, 3995-4008, https://doi.org/10.1128/JVI.06540-11.

16. Su, S.; Wong, G.; Shi, W.; Liu, J.; Lai, A.C.K.; Zhou, J.; Liu, W.; Bi, Y.; Gao, G.F. Epidemiology, Genetic Recombination, and Pathogenesis of Coronaviruses. Trends in Microbiology 2016, 24, 490-502, https://doi.org/10.1016/j.tim.2016.03.003.

17. Simon, A.; Volz, S.; Hofling, K.; Kehl, A.; Tillman, R.; Muller, A.; Kupfer, B.; Eis-Hubinger, A.M.; Lentze, M.J.; Bode, U.; Schildgen, O. Acute life threatening event (ALTE) in an infant with human coronavirus HCoV-229E infection. Pediatr Pulmonol 2007, 42, 393-396, https://doi.org/10.1002/ppul.20595.

18. Lau, S.K.; Li, K.S.; Tsang, A.K.; Shek, C.T.; Wang, M.; Choi, G.K.; Guo, R.; Wong, B.H.; Poon, R.W.; Lam, C.S.; Wang, S.Y.; Fan, R.Y.; Chan, K.H.; Zheng, B.J.; Woo, P.C.; Yuen, K.Y. Recent transmission of a novel alphacoronavirus, bat coronavirus HKU10, from Leschenault's rousettes to pomona leaf-nosed bats: first evidence of interspecies transmission of coronavirus between bats of different suborders. J Virol 2012, 86, 11906-11918, https://doi.org/10.1128/jvi.01305-12.

19. Morfopoulou, S.; Brown, J.; Davies, E.; Anderson, G.; Virasami, A.; Qasim, W.; Chong, W.; Hubank, M.; Plagnol, V.; Desforges, M.; Jacques, T.; Talbot, P.; Breuer, J. Human Coronavirus OC43 Associated with Fatal Encephalitis. New England Journal of Medicine 2016, 375, 497-498, https://doi.org/10.1056/NEJMc1509458.

20. Mayer, K.; Nellessen, C.; Hahn-Ast, C.; Schumacher, M.; Pietzonka, S.; Eis-Hubinger, A.M.; Drosten, C.; Brossart, P.; Wolf, D. Fatal outcome of human coronavirus NL63 infection despite successful viral elimination by IFN-alpha in a patient with newly diagnosed ALL. Eur J Haematol 2016, 97, 208-210, https://doi.org/10.1111/ejh.12744.

21. Al-Khannaq, M.N.; Ng, K.T.; Oong, X.Y.; Pang, Y.K.; Takebe, Y.; Chook, J.B.; Hanafi, N.S.; Kamarulzaman, A.; Tee, K.K. Molecular epidemiology and evolutionary histories of human coronavirus OC43 and HKU1 among patients with upper respiratory tract infections in Kuala Lumpur, Malaysia. Virol J 2016, 13, 33, https://doi.org/10.1186/s12985-016-0488-4.

22. Oong, X.Y. ; Ng, K.T.; Takebe, Y.; Ng, L.J.; Chan, K.G.; Chook, J.B.; Kamarulzaman, A.; Tee, K.K. Identification and evolutionary dynamics of two novel human coronavirus OC43 genotypes associated with acute respiratory infections: Phylogenetic, spatiotemporal and transmission network analyses. Emerg. Microbes Infect. 2017, 6, https://doi.org/10.1038/emi.2016.132.

23. Lau, S.K.; Lee, P.; Tsang, A.K.; Yip, C.C.; Tse, H.; Lee, R.A.; So, L.Y.; Lau, Y.L.; Chan, K.H.; Woo, P.C.; Yuen, K.Y. Molecular epidemiology of human coronavirus OC43 reveals evolution of different genotypes over time and recent emergence of a novel genotype due to natural recombination. J Virol 2011, 85, 1132511337, https://doi.org/10.1128/jvi.05512-11.

24. Menachery, V.D.; Yount, B.L., Jr.; Sims, A.C.; Debbink, K.; Agnihothram, S.S.; Gralinski, L.E.; Graham, R.L.; Scobey, T.; Plante, J.A.; Royal, S.R.; Swanstrom, J.; Sheahan, T.P.; Pickles, R.J.; Corti, D.; Randell, S.H.; Lanzavecchia, A.; Marasco, W.A.; Baric, R.S. SARS-like WIV1-CoV poised for human emergence. Proc Natl Acad Sci U S A 2016, 113, 3048-3053, https://doi.org/10.1073/pnas.1517719113. 
25. Yang, Y.; Liu, C.; Du, L. Y.; Jiang, S.; Shi, Z.; Baric, R.S.; Li, F. Two mutations were critical for bat-tohuman transmission of Middle East Respiratory Syndrome coronavirus. J. Virol. 2015, 89, 9119-9123, https://doi.org/10.1128/JVI.01279-15.

26. De Haan, C.A.; Rottier, P.J. Molecular interactions in the assembly of coronaviruses. Adv Virus Res. 2005, 64, 165-230, https://doi.org/10.1016/S0065-3527(05)64006-7.

27. Masters, P.S. The molecular biology of coronaviruses. Adv Virus Res. 2006, 66, 193-292, https://doi.org/10.1016/S0065-3527(06)66005-3.

28. Graham, R.L.; Baric, R.S. Recombination, reservoirs, and the modular spike: mechanisms of coronavirus cross-species transmission. J Virol. 2010, 84, 3134-3146, https://doi.org/10.1128/JVI.01394-09.

29. Bárcena, M.; Oostergetel, G.T.; Bartelink, W.; Faas, F.G.A.; Verkleij, A.; Rottier, P.J.M.; Koster, A.J.; Bosch, B.J. Cryo-electron tomography of mouse hepatitis virus: Insights into the structure of the coronavirion. Proceedings of the National Academy of Sciences 2009, 106, 582, https://doi.org/10.1073/pnas.0805270106.

30. Lewicki, D.N.; Gallagher, T.M. Quaternary structure of coronavirus spikes in complex with carcinoembryonic antigen- related cell adhesion molecule cellular receptors. J Biol Chem. 2002, 277, 1972719734, https://doi.org/10.1074/jbc.M201837200.

31. de Haan, C.A.M.; de Wit, M.; Kuo, L.; Montalto-Morrison, C.; Haagmans, B.L.; Weiss, S.R.; Masters, P.S.; Rottier, P.J.M. The glycosylation status of the murine hepatitis coronavirus $M$ protein affects the interferogenic capacity of the virus in vitro and its ability to replicate in the liver but not the brain. Virology 2003, 312, 395-406, https://doi.org/10.1016/S0042-6822(03)00235-6.

32. Raamsman, M.; Locker, J.; Hooge, A.; De Vries, A.; Griffiths, G.; Vennema, H.; Rottier, P. Characterization of the Coronavirus Mouse Hepatitis Virus Strain A59 Small Membrane Protein E. J Virol 2000, 74, 23332342, https://doi.org/10.1128/JVI.74.5.2333-2342.2000.

33. Blau, D.M.; Holmes, K.V. Human coronavirus HCoV-229E enters susceptible cells via the endocytic pathway. Adv Exp Med Biol. 2001, 494, 193-8, https://doi.org/10.1007/978-1-4615-1325-4_31.

34. Chu, V.C.; McElroy, L.J.; Ferguson, A.D.; Bauman, B.E.; Whittaker, G.R. Avian infectious bronchitis virus enters cells via the endocytic pathway. Adv Exp Med Biol. 2006, 581, 309-312, https://doi.org/10.1007/9780-387-33012-9_54.

35. Eifart, P.; Ludwig, K.; Bottcher, C.; de Haan, C.A.; Rottier, P.J.; Korte, T.; Herrmann, A. Role of endocytosis and low $\mathrm{pH}$ in murine hepatitis virus strain A59 cell entry. J Virol 2007, 81, 10758-10768, https://doi.org/10.1128/jvi.00725-07.

36. Wang, H.; Yang, P.; Liu, K.; Guo, F.; Zhang, Y.; Zhang, G.; Jiang, C. SARS coronavirus entry into host cells through a novel clathrin- and caveolae-independent endocytic pathway. Cell Res 2008, 18, 290-301, https://doi.org/10.1038/cr.2008.15.

37. Weiss, S.R.; Navas-Martin, S. Coronavirus pathogenesis and the emerging pathogen severe acute respiratory syndrome coronavirus. Microbiol Mol Biol Rev 2005, 69, 635-664, https://doi.org/10.1128/MMBR.69.4.635-664.2005.

38. Goldsmith, C.S.; Tatti, K.M.; Ksiazek, T.G.; Rollin, P.E.; Comer, J.A.; Lee, W.W.; Rota, P.A.; Bankamp, B.; Bellini, W.J.; Zaki, S.R. Ultrastructural characterization of SARS coronavirus. Emerg Infect Dis 2004, 10, 320-326, https://doi.org/10.3201/eid1002.030913.

39. Gosert, R.; Kanjanahaluethai, A.; Egger, D.; Bienz, K.; Baker, S.C. RNA replication of mouse hepatitis virus takes place at double-membrane vesicles. J Virol 2002, 76, 3697-3708, https://doi.org/10.1128/jvi.76.8.3697-3708.2002.

40. Ng, M.L.; Tan, S.H., See, E.E.; Ooi, E.E.; Ling, A.E. Proliferative growth of SARS coronavirus in Vero E6 cells. J Gen Virol. 2003, 84, 3291-3303, https://doi.org/10.1099/vir.0.19505-0.

41. Kuo, L.; Masters, P.S. Genetic evidence for a structural interaction between the carboxy termini of the membrane and nucleocapsid proteins of mouse hepatitis virus. J Virol 2002, 76, 4987-4999, https://doi.org/10.1128/jvi.76.10.4987-4999.2002.

42. Keane, S.C.; Giedroc, D.P. Solution of Mouse Hepatit Virus (MHV) nsp3a and determinants of the interaction with MHV nucleocapsid (N) protein. $J$ Virol. 2013, 87, 3502-3515, https://dx.doi.org/10.1128\%2FJVI.03112-12.

43. Keane, S.C.; Giedroc, D.P. Solution structure of mouse hepatitis virus (MHV) nsp3a and determinants of the interaction with MHV nucleocapsid (N) protein. $J$ Virol 2013, 87, 3502-3515, https://doi.org/10.1128/JVI.03112-12.

44. Bosch, B.J.; Van Der Zee, R.; de Haan, C.A.M.; Rottier, P.J.M. The coronavirus spike protein is a class I virus fusion protein: structural and functional characterization of the fusion core complex. J. Virol. 2003, 77, 8801-8811, https://doi.org/10.1128/jvi.77.16.88018811.2003.

45. Baker, K.A.; Dutch, R.E.; Lamb, R.A.; Jardetzky, T.S. Structural Basis for Paramyxovirus-Mediated Membrane Fusion. Molecular Cell 1999, 3, 309-319, https://doi.org/10.1016/S1097-2765(00)80458-X. 
46. Bartesaghi, A.; Merk, A.; Borgnia, M.J.; Milne, J.L.S.; Subramaniam, S. Prefusion structure of trimeric HIV1 envelope glycoprotein determined by cryo-electron microscopy. Nature Structural \& Molecular Biology 2013, 20, 1352-1357, http://dx.doi.org/10.1038/nsmb.2711.

47. Lin, X.; Eddy, N.R.; Noel, J.K.; Whitford, P.C.; Wang, Q.; Ma, J.; Onuchic, J.N. Order and disorder control the functional rearrangement of influenza hemagglutinin. Proceedings of the National Academy of Sciences 2014, 111, 12049-12054, http://dx.doi.org/10.1073/pnas.1412849111.

48. Hofmann, H.; Hattermann, K.; Marzi, A.; Gramberg, T.; Geier, M.; Krumbiegel, M.; Kuate, S.; Überla, K.; Niedrig, M.; Pöhlmann, S. S Protein of Severe Acute Respiratory Syndrome-Associated Coronavirus Mediates Entry into Hepatoma Cell Lines and Is Targeted by Neutralizing Antibodies in Infected Patients. $J$ Virol 2004, 78, 6134-6142, http://dx.doi.org/10.1128/JVI.78.12.6134-6142.2004.

49. Walls, A.C.; Tortorici, M.A.; Bosch, B.-J.; Frenz, B.; Rottier, P.J.M.; DiMaio, F.; Rey, F.A.; Veesler, D. Cryo-electron microscopy structure of a coronavirus spike glycoprotein trimer. Nature 2016, 531, 114-117, http://dx.doi.org/10.1038/nature16988.

50. Kirchdoerfer, R.N.; Cottrell, C.A.; Wang, N.; Pallesen, J.; Yassine, H.M.; Turner, H.L.; Corbett, K.S.; Graham, B.S.; McLellan, J.S.; Ward, A.B. Pre-fusion structure of a human coronavirus spike protein. Nature 2016, 531, 118-121, http://dx.doi.org/10.1038/nature17200.

51. Reguera, J.; Santiago, C.; Mudgal, G.; Ordoño, D.; Enjuanes, L.; Casasnovas, J.M. Structural bases of coronavirus attachment to host aminopeptidase $\mathrm{N}$ and its inhibition by neutralizing antibodies. PLoS Pathog 2012, 8, e1002859-e1002859, https://doi.org/10.1371/journal.ppat.1002859.

52. Xu, L., Liu, H., Murray, B.P., et al. Cobicistat (GS-9350): A Potent and Selective Inhibitor of Human CYP3A as a Novel Pharmacoenhancer. ACS Med Chem Lett. 2010, 1(5), 209-213. doi:10.1021/ml1000257

53. Wu, K.; Li, W.; Peng, G.; Li, F. Crystal structure of NL63 respiratory coronavirus receptor-binding domain complexed with its human receptor. Proc Natl Acad Sci U S A 2009, 106, 19970-19974, https://doi.org/10.1073/pnas.0908837106.

54. Duquerroy, S.; Vigouroux, A.; Rottier, P.J.; Rey, F.A.; Bosch, B.J. Central ions and lateral asparagine/glutamine zippers stabilize the post-fusion hairpin conformation of the SARS coronavirus spike glycoprotein. Virology 2005, 335, 276-285, https://doi.org/10.1016/j.virol.2005.02.022.

55. Gao, J.; Lu, G.; Qi, J.; Li, Y.; Wu, Y.; Deng, Y.; Geng, H.; Li, H.; Wang, Q.; Xiao, H.; Tan, W.; Yan, J.; Gao, G.F. Structure of the Fusion Core and Inhibition of Fusion by a Heptad Repeat Peptide Derived from the S Protein of Middle East Respiratory Syndrome Coronavirus. J Virol 2013, 87, 13134-13140, http://dx.doi.org/10.1128/JVI.02433-13.

56. Xu, Y.; Lou, Z.; Liu, Y.; Pang, H.; Tien, P.; Gao, G.F.; Rao, Z. Crystal structure of severe acute respiratory syndrome coronavirus spike protein fusion core. J Biol Chem 2004, 279, 49414-49419, http://dx.doi.org/10.1074/jbc.M408782200.

57. Ou, X.; Zheng, W.; Shan, Y.; Mu, Z.; Dominguez, S.R.; Holmes, K.V.; Qian, Z. Identification of the Fusion Peptide-Containing Region in Betacoronavirus Spike Glycoproteins. J Virol 2016, 90, 5586-5600, https://doi.org/10.1128/jvi.00015-16.

58. Lu, G.; Hu, Y.; Wang, Q.; Qi, J.; Gao, F.; Li, Y.; Zhang, Y.; Zhang, W.; Yuan, Y.; Bao, J.; Zhang, B.; Shi, Y.; Yan, J.; Gao, G.F. Molecular basis of binding between novel human coronavirus MERS-CoV and its receptor CD26. Nature 2013, 500, 227-231, http://dx.doi.org/10.1038/nature12328.

59. Lu, L.; Liu, Q.; Zhu, Y.; Chan, K.-H.; Qin, L.; Li, Y.; Wang, Q.; Chan, J.F.-W.; Du, L.; Yu, F.; Ma, C.; Ye, S.; Yuen, K.-Y.; Zhang, R.; Jiang, S. Structure-based discovery of Middle East respiratory syndrome coronavirus fusion inhibitor. http://dx.doi.org/10.1038/ncomms4067.

60. Huey, R.; Morris, G. AutoDock Tools. The Scripps Research Institute: La Jolla, CA, USA, 2003.

61. Shang, J.; Ye, G.; Shi, K.; Wan, Y.S.; Aihara, H.; Li, F. Structural basis for resptor recognition by novel coronavirus from wuhan, Structural biology virology 2020, 03-04, https://doi.org/10.21203/rs.2.24749/v1.

62. Xia, S.; Yan, L.; Xu, W.; Agrawal, A.S.; Algaissi, A.; Tseng, C.K.; Wang, Q.; Du, L.; Tan, W.; Wilson, I.A.; Jiang, S.; Yang, B.; Lu, L. A pan-coronavirus fusion inhibitor targeting the HR1 domain of human coronavirus spike. Sci Adv 2019, 5, eaav4580-eaav4580, https://doi.org/doi:10.1126/sciadv.aav4580.

63. Kirchdoerfer, R.N.; Ward, A.B. Structure of the SARS-CoV nsp12 polymerase bound to nsp7 and nsp8 cofactors. Nature Communications 2019, 10, 2342-2342, https://doi.org/10.1038/s41467-019-10280-3.

64. Báez-Santos, Y.M.; Barraza, S.J.; Wilson, M.W.; Agius, M.P.; Mielech, A.M.; Davis, N.M.; Baker, S.C.; Larsen, S.D.; Mesecar, A.D. X-ray Structural and Biological Evaluation of a Series of Potent and Highly Selective Inhibitors of Human Coronavirus Papain-like Proteases. Journal of Medicinal Chemistry 2014, 57, 2393-2412, https://doi.org/10.1021/jm401712t.

65. Mollaamin, F.; Monajjemi, M. DFT outlook of solvent effect on function of nano bioorganic drugs. Physics and Chemistry of Liquids 2012, 50, 596-604, https://doi.org/10.1080/00319104.2011.646444.

66. Mollaamin, F.; Gharibe, S.; Monajjemi, M. Synthesis of various nano and micro ZnSe morphologies by using hydrothermal method. International Journal of Physical Sciences 2011, 6, 1496-1500. 
67. Monajjemi M. Graphene/(h-BN)n/X-doped raphene as anode material in lithium ion batteries $(\mathrm{X}=\mathrm{Li}, \mathrm{Be}$, B AND N). Macedonian Journal of Chemistry and Chemical Engineering 2017, 36, 101-118, http://dx.doi.org/10.20450/mjcce.2017.1134.

68. Monajjemi, M. Cell membrane causes the lipid bilayers to behave as variable capacitors: A resonance with self-induction of helical proteins. Biophysical Chemistry 2015, 207, 114-127, https://doi.org/10.1016/j.bpc.2015.10.003.

69. Monajjemi, M. Study of CD5+ Ions and Deuterated Variants $(\mathrm{CHxD}(5-\mathrm{x})+)$ : An Artefactual Rotation. Russian Journal of Physical Chemistry A 2018, 92, 2215-2226.

70. Monajjemi, M. Liquid-phase exfoliation (LPE) of graphite towards graphene: An ab initio study. Journal of Molecular Liquids, 2017, 230, 461-472, https://doi.org/10.1016/j.molliq.2017.01.044.

71. Jalilian, H.; Monajjemi, M. Capacitor simulation including of $\mathrm{X}$-doped graphene $(\mathrm{X}=\mathrm{Li}, \mathrm{Be}, \mathrm{B})$ as two electrodes and $(\mathrm{h}-\mathrm{BN}) \mathrm{m}(\mathrm{m}=1-4)$ as the insulator. Japanese Journal 2015, 54, 085101-7.

72. Ardalan, T.; Ardalan, P.; Monajjemi, M. Nano theoretical study of a C 16 cluster as a novel material for vitamin C carrier. Fullerenes Nanotubes and Carbon Nanostructures 2014, 22, 687-708, https://doi.org/10.1080/1536383X.2012.717561.

73. Mahdavian, L.; Monajjemi, M.; Mangkorntong, N. Sensor response to alcohol and chemical mechanism of carbon nanotube gas sensors Fullerenes Nanotubes and Carbon Nanostructures 2009, 17, 484-495, https://doi.org/10.1080/15363830903130044.

74. Monajjemi, M.; Najafpour, J. Charge density discrepancy between NBO and QTAIM in single-wall armchair carbon nanotubes. Fullerenes Nanotubes and Carbon 594, https://doi.org/10.1080/1536383X.2012.702161.

75. Monajjemi, M.; Hosseini, M.S. Non bonded interaction of B16 N16 nano ring with copper cations in point of crystal fields. Journal of Computational and Theoretical Nanoscience 2013, 10, 2473- 2477

76. Monajjemi, M.; Mahdavian, L.; Mollaamin, F. Characterization of nanocrystalline silicon germanium film and nanotube in adsorption gas by Monte Carlo and Langevin dynamic simulation. Bulletin of the Chemical Society of Ethiopia 2008, 22, 277-286, https://doi.org/10.4314/bcse.v22i2.61299.

77. Lee, V.S.; Nimmanpipug, P.; Mollaamin, F.; Thanasanvorakun, S.; Monajjemi, M. Investigation of single wall carbon nanotubes electrical properties and normal mode analysis: Dielectric effects. Russian Journal of Physical Chemistry A 2009, 83, 2288-2296, https://doi.org/10.1134/S0036024409130184.

78. Mollaamin, F.; Najafpour, J.; Ghadami, S.; Akrami, M.S.; Monajjemi, M. The electromagnetic feature of B $\mathrm{N} \mathrm{H}(\mathrm{x}=0,4,8,12,16$, and 20) nano rings:Quantum theory of atoms in molecules/NMR approach. Journal of Computational and Theoretical Nanoscience 2014, 11, 1290-1298.

79. Monajjemi, M.; Mahdavian, L.; Mollaamin, F.; Honarparvar, B. Thermodynamic investigation of enolketo tautomerism for alcohol sensors based on carbon nanotubes as chemical sensors. Fullerenes Nanotubes and Carbon Nanostructures 2010, 18, 45-55, https://doi.org/10.1080/15363830903291564.

80. Monajjemi, M.; Ghiasi, R.; Seyed, S.M.A. Metal-stabilized rare tautomers: N4 metalated cytosine $(\mathrm{M}=\mathrm{Li}$, $\mathrm{Na}, \mathrm{K}, \mathrm{Rb}$ and $\mathrm{Cs}$ ), theoretical views. Applied Organometallic Chemistry 2003, 17, 635-640, https://doi.org/10.1002/aoc.469.

81. Ilkhani, A.R.; Monajjemi, M. The pseudo Jahn-Teller effect of puckering in pentatomic unsaturated rings C $\mathrm{AE}, \mathrm{A}=\mathrm{N}, \mathrm{P}, \mathrm{As}, \mathrm{E}=\mathrm{H}, \mathrm{F}, \mathrm{Cl}$.Computational and Theoretical Chemistry 2015, 1074,19-25, http://dx.doi.org/10.1016\%2Fj.comptc.2015.10.006.

82. Monajjemi, $\mathrm{M}$. Non-covalent attraction of $\mathrm{B} \mathrm{N}$ and repulsion of $\mathrm{B} \mathrm{N}$ in the $\mathrm{B} \mathrm{N}$ ring: a quantum rotatory due to an external field. Theoretical Chemistry Accounts 2015, 134, 1-22, https://doi.org/10.1007/s00214-0151668-9.

83. Monajjemi, M.; Naderi, F.; Mollaamin, F.; Khaleghian, M. Drug design outlook by calculation of second virial coefficient as a nano study. Journal of the Mexican Chemical Society 2012, 56, 207-211, https://doi.org/10.29356/jmcs.v56i2.323. .

84. Monajjemi, M.; Bagheri, S.; Moosavi, M.S. Symmetry breaking of B2N(-,0,+): An aspect of the electric potential and atomic charges. Molecules 2015, 20, 21636-21657, https://doi.org/10.3390/molecules201219769.

85. Monajjemi, M.; Mohammadian, N.T. S-NICS: An aromaticity criterion for nano molecules. Journal of Computational and Theoretical Nanoscience 2015, 12, 4895-4914, https://doi.org/10.1166/jctn.2015.4458.

86. Monajjemi, M.; Ketabi, S.; Hashemian, Z.M.; Amiri, A. Simulation of DNA bases in water: Comparison of the Monte Carlo algorithm with molecular mechanics force fields. Biochemistry (Moscow) 2006, 71, 1-8, https://doi.org/10.1134/s0006297906130013.

87. Monajjemi, M.; Lee, V.S.; Khaleghian, M.; Honarparvar, B.; Mollaamin, F. Theoretical Description of Electromagnetic Nonbonded Interactions of Radical, Cationic, and Anionic NH2BHNBHNH2 Inside of the B18N18 Nanoring. J. Phys. Chem C 2010, 114, 15315-15330, https://doi.org/10.1021/jp104274z.

88. Monajjemi, M.; Boggs, J.E. A New Generation of BnNn Rings as a Supplement to Boron Nitride Tubes and Cages. J. Phys. Chem. A 2013, 117, 1670-1684, http://dx.doi.org/10.1021/jp312073q. 
89. Monajjemi, M. Non bonded interaction between BnNn (stator) and BN B (rotor) systems: A quantum rotation in IR region. Chemical Physics 2013, 425, 29-45, https://doi.org/10.1016/j.chemphys.2013.07.014.

90. Monajjemi, M.; Robert, W.J.; Boggs, J.E. NMR contour maps as a new parameter of carboxyl's OH groups in amino acids recognition: A reason of tRNA-amino acid conjugation. Chemical Physics 2014, 433, 1-11, https://doi.org/10.1016/j.chemphys.2014.01.017.

91. Monajjemi, M. Quantum investigation of non-bonded interaction between the B15N15 ring and BH2NBH2 (radical, cation, and anion) systems: a nano molecularmotor. Struct Chem 2012, 23, 551-580, http://dx.doi.org/10.1007/s11224-011-9895-8.

92. Monajjemi, M. Metal-doped graphene layers composed with boron nitride-graphene as an insulator: a nanocapacitor. Journal of Molecular Modeling 2014, 20, 2507, https://doi.org/10.1007/s00894-014-2507-y.

93. Mollaamin, F.; Monajjemi, M.; Mehrzad, J. Molecular Modeling Investigation of an Anti-cancer Agent Joint to SWCNT Using Theoretical Methods. Fullerenes, Nanotubes and Carbon Nanostructures 2014, 22, 738751, https://doi.org/10.1080/1536383X.2012.731582.

94. Monajjemi, M.; Ketabi, S.; Amiri, A. Monte Carlo simulation study of melittin: protein folding and temperature ependence. Russian journal of physical chemistry 2006, 80, S55-S62, https://doi.org/10.1134/S0036024406130103.

95. Monajjemi, M.; Heshmata, M.; Haeria, H.H. QM/MM model study on properties and structure of some antibiotics in gas phase: Comparison of energy and NMR chemical shift. Biochemistry (Moscow) 2006, 71, S113-S122, https://doi.org/10.1134/S0006297906130190.

96. Monajjemi, M.; Afsharnezhad, S.; Jaafari, M.R.; Abdolahi, T.; Nikosade, A.; Monajemi, H. NMR shielding and a thermodynamic study of the effect of environmental exposure to petrochemical solvent on DPPC, an important component of lung surfactant. Russian Journal of Physical Chemistry A 2007, 81, 1956-1963, https://doi.org/10.1134/S0036024407120096.

97. Mollaamin, F.; Noei, M.; Monajjemi, M.; Rasoolzadeh, R. Nano theoretical studies of fMET-tRNA structure in protein synthesis of prokaryotes and its comparison with the structure of fALA-tRNA. African journal of microbiology research 2011, 5, 2667-2674, https://doi.org/10.5897/AJMR11.310.

98. Monajjemi, M.; Heshmat, M.; Haeri, H.H.; Kaveh, F. Theoretical study of vitamin properties from combined QM-MM methods: Comparison of chemical shifts and energy. Russian Journal of Physical Chemistry 2006, 80, 1061-1068, https://doi.org/10.1134/S0036024406070119.

99. Monajjemi, M.; Chahkandi, B. Theoretical investigation of hydrogen bonding in Watson-Crick, Hoogestein and their reversed and other models: comparison and analysis for configurations of adenine-thymine base pairs in 9 models. Journal of Molecular Structure: THEOCHEM 2005, 714, 43-60, https://doi.org/10.1016/j.theochem.2004.09.048.

100. Monajjemi, M.; Honarparvar, B.; Haeri, H.H.; Heshmat, M. An ab initio quantum chemical investigation of solvent-induced effect on $14 \mathrm{~N}-\mathrm{NQR}$ parameters of alanine, glycine, valine, and serine using a polarizable continuum model. Russian Journal of Physical Chemistry 2006, 80, S40-S44, https://doi.org/10.1134/S0036024406130073.

101. Monajjemi, M.; Seyed Hosseini, M. Non Bonded Interaction of B16N16 Nano Ring with Copper Cations in Point of Crystal Fields. Journal of Computational and Theoretical Nanoscience 2013, 10, 2473-2477, https://doi.org/10.1166/jctn.2013.3233.

102. Monajjemi, M.; Farahani, N.; Mollaamin, F. Thermodynamic study of solvent effects on nanostructures: phosphatidylserine and phosphatidylinositol membranes. Physics and Chemistry of Liquids 2012, 50, 161172, https://doi.org/10.1080/00319104.2010.527842.

103. Monajjemi, M.; Ahmadianarog, M. Carbon Nanotube as a Deliver for Sulforaphane in Broccoli Vegetable in Point of Nuclear Magnetic Resonance and Natural Bond Orbital Specifications. Journal of Computational and Theoretical Nanoscience 2014, 11, 1465-1471, https://doi.org/10.1166/jctn.2014.3519.

104. Monajjemi, M.; Ghiasi, R.; Ketabi, S.; Passdar, H.; Mollaamin, F. A Theoretical Study of Metal-Stabilised Rare Tautomers Stability: N4 Metalated Cytosine $\left(\mathrm{M}=\mathrm{Be}^{2+}, \mathrm{Mg}^{2+}, \mathrm{Ca}^{2+}, \mathrm{Sr}^{2+}\right.$ and $\left.\mathrm{Ba}^{2+}\right)$ in $\mathrm{Gas}$ Phase and Different, Journal of Chemical Research 2004, 1, 11-18.

105. Monajjemi, M.; Baei, M.T.; Mollaamin, F. Quantum mechanic study of hydrogen chemisorptions on nanocluster vanadium surface. Russian Journal of Inorganic https://doi.org/10.1134/S0036023608090143.

106. Mollaamin, F.; Baei, M.T.; Monajjemi, M.; Zhiani, R.; Honarparvar, B. A DFT study of hydrogen chemisorption on V (100) surfaces. Russian Journal of Physical Chemistry A, Focus on Chemistry 2008, 82, 2354-2361, https://doi.org/10.1134/S0036024408130323.

107. Monajjemi, M.; Honarparvar, B.; Nasseri, S.M.; Khaleghian, M. NQR and NMR study of hydrogen bonding interactions in anhydrous and monohydrated guanine cluster model: A computational study. Journal of Structural Chemistry 2009, 50, 67-77, https://doi.org/10.1007/s10947-009-0009-z.

108. Monajjemi, M.; Aghaie, H.; Naderi, F. Thermodynamic study of interaction of TSPP, CoTsPc, and FeTsPc with calf thymus DNA. Biochemistry (Moscow) 2007, 72, 652-657, https://doi.org/10.1134/S0006297907060089. 
109. Monajjemi, M.; Heshmat, M.; Aghaei, H.; Ahmadi, R.; Zare, K. Solvent effect on 14N NMR shielding of glycine, serine, leucine, and threonine: Comparison between chemical shifts and energy versus dielectric constant. Bulletin of the Chemical Society of Ethiopia 2007, 21, 111-116, https://doi.org/10.4314/bcse.v21i1.61387.

110. Monajjemi, M.; Rajaeian, E.; Mollaamin, F.; Naderi, F.; Saki, S. Investigation of NMR shielding tensors in 1,3 dipolar cycloadditions: solvents dielectric effect. Physics and Chemistry of Liquids 2008, 46, 299-306, https://doi.org/10.1080/00319100601124369.

111. Mollaamin, F.; Varmaghani, Z.; Monajjemi, M. Dielectric effect on thermodynamic properties in vinblastine by DFT/Onsager modelling. Physics and Chemistry of Liquids 2011, 49, 318-336, https://doi.org/10.1080/00319100903456121.

112. Monajjemi, M.; Honaparvar, B.; Khalili Hadad, B.; Ilkhani, A.; Mollaamin, F. Thermo-Chemical Investigation and NBO Analysis of Some anxileotic as Nano- Drugs. African journal of pharmacy and pharmacology 2010, 4, 521-529.

113. Monajjemi, M.; Khaleghian, M.; Mollaamin, F. Theoretical study of the intermolecular potential energy and second virial coefficient in the mixtures of $\mathrm{CH} 4$ and $\mathrm{Kr}$ gases: a comparison with experimental data. Molecular Simulation 2010, 36, 865-870, https://doi.org/10.1080/08927022.2010.489557.

114. Monajjemi, M.; Khosravi, M.; Honarparvar, B.; Mollaamin, F. Substituent and solvent effects on the structural bioactivity and anticancer characteristic of catechin as a bioactive constituent of green tea. International Journal of Quantum Chemistry 2011, 111, 2771-2777, https://doi.org/10.1002/qua.22612.

115. Tahan, A.; Monajjemi, M. Solvent dielectric effect and side chain mutation on the structural stability of Burkholderia cepacia lipase active site: a quantum mechanical/molecular mechanics study. Acta Biotheor 2011, 59, 291-312, https://doi.org/10.1007/s10441-011-9137-x.

116. Monajjemi, M.; Khaleghian, M. EPR Study of Electronic Structure of [CoF6]3-and B18N18 Nano Ring Field Effects on Octahedral Complex. Journal of Cluster Science 2011, 22, 673-692, https://doi.org/10.1007/s10876-011-0414-2.

117. Monajjemi, M.; Mollaamin, F. Molecular Modeling Study of Drug-DNA Combined to Single Walled Carbon Nanotube. Journal of Cluster Science 2012, 23, 259-272, https://doi.org/10.1007/s10876-011-0426-y.

118. Mollaamin, F.; Monajjemi, M. Fractal Dimension on Carbon Nanotube-Polymer Composite Materials Using Percolation Theory. Journal of Computational and Theoretical Nanoscience 2012, 9, 597-601, https://doi.org/10.1166/jctn.2012.2067.

119. Mahdavian, L.; Monajjemi, M. Alcohol sensors based on SWNT as chemical sensors: Monte Carlo and Langevin dynamics simulation. Microelectronics Journal 2010, 41, 142-149, https://doi.org/10.1016/j.mejo.2010.01.011.

120. Monajjemi, M.; Falahati, M.; Mollaamin, F. Computational investigation on alcohol nanosensors in combination with carbon nanotube: a Monte Carlo and ab initio simulation. Ionics 2013, 19, 155-164, https://doi.org/10.1007/s11581-012-0708-X.

121. Li, F. Receptor Recognition Mechanisms of Coronaviruses: a Decade of Structural Studies. J Virol 2015 , 89, 1954-1964, http://dx.doi.org/10.1128/JVI.02615-14.

122. Bonavia, A.; Zelus, B.D.; Wentworth, D.E.; Talbot, P.J.; Holmes, K.V. Identification of a receptor-binding domain of the spike glycoprotein of human coronavirus HCoV-229E. J Virol 2003, 77, 2530-2538, http://dx.doi.org/10.1128/JVI.77.4.2530-2538.2003.

123. Reguera, J.; Santiago, C.; Mudgal, G.; Ordoño, D.; Enjuanes, L.; Casasnovas, J.M. Structural Bases of Coronavirus Attachment to Host Aminopeptidase $\mathrm{N}$ and Its Inhibition by Neutralizing Antibodies. PLoS Pathog 2012, 8, e1002859, http://dx.doi.org/10.1371/journal.ppat.1002859.

124. Li, W.; Zhang, C.; Sui, J.; Kuhn, J.H.; Moore, M.J.; Luo, S.; Wong, S.-K.; Huang, I.C.; Xu, K.; Vasilieva, N.; Murakami, A.; He, Y.; Marasco, W.A.; Guan, Y.; Choe, H.; Farzan, M. Receptor and viral determinants of SARS-coronavirus adaptation to human ACE2. The EMBO Journal 2005, 24, 1634-1643, http://dx.doi.org/10.1038/sj.emboj.7600640.

125. Lu, G.; Hu, Y.; Wang, Q.; Qi, J.; Gao, F.; Li, Y.; Zhang, Y.; Zhang, W.; Yuan, Y.; Bao, J.; Zhang, B.; Shi, Y.; Yan, J.; Gao, G.F. Molecular basis of binding between novel human coronavirus MERS-CoV and its receptor CD26. Nature 2013, 500, 227-231, http://dx.doi.org/10.1038/nature12328.

126. Mou, H.; Raj, V.S.; van Kuppeveld, F.J.M.; Rottier, P.J.M.; Haagmans, B.L.; Bosch, B.J. The receptor binding domain of the new Middle East respiratory syndrome coronavirus maps to a 231-residue region in the spike protein that efficiently elicits neutralizing antibodies. J. Virol. 2013, 87, 9379-9383, http://dx.doi.org/10.1128/JVI.01277-13.

127. Raj, V.S.; Mou, H.; Smits, S.L.; Dekkers, D.H.W.; Müller, M.A.; Dijkman, R.; Muth, D.; Demmers, J.A.A.; Zaki, A.; Fouchier, R.A.M.; Thiel, V.; Drosten, C.; Rottier, P.J.M.; Osterhaus, A.D.M.E.; Bosch, B.J.; Haagmans, B.L. Dipeptidyl peptidase 4 is a functional receptor for the emerging human coronavirus-EMC. Nature 2013, 495, 251-254, http://dx.doi.org/10.1038/nature12005. 
128. Yang, Y.; Du, L.; Liu, C.; Wang, L.; Ma, C.; Tang, J.; Baric, R.S.; Jiang, S.; Li, F. Receptor usage and cell entry of bat coronavirus HKU4 provide insight into bat-to-human transmission of MERS coronavirus. Proc Natl Acad Sci U S A 2014, 111, 12516-12521, http://dx.doi.org/10.1073/pnas.1405889111.

129. Yang, Y.; Liu, C.; Du, L.; Jiang, S.; Shi, Z.; Baric, R.S.; Li, F. Two Mutations Were Critical for Bat-toHuman Transmission of Middle East Respiratory Syndrome Coronavirus. J Virol 2015, 89, 9119-9123, http://dx.doi.org/10.1128/JVI.01279-15.

130. Promkuntod, N.; van Eijndhoven, R.; de Vrieze, G.; Grone, A.; Verheije, M.; Mapping of the receptorbinding domain and amino acids critical for attachment in the spike protein of avian coronavirus infectious bronchitis virus. Virology 2014, 448, 26-32, http://dx.doi.org/10.1016/j.virol.2013.09.018.

131. Peng, G.; Sun, D.; Rajashankar, K.R.; Qian, Z.; Holmes, K.V.; Li, F. Crystal structure of mouse coronavirus receptor-binding domain complexed with its murine receptor. Proc Natl Acad Sci U S A 2011, 108, 1069610701, http://dx.doi.org/10.1073/pnas.104306108.

132. Peng, G.; Xu, L.; Lin, Y.L.; Chen, L.; Pasquarella, J.R.; Holmes, K.V.; Li, F. Crystal structure of bovine coronavirus spike protein lectin domain. J. Biol. Chem. 2012, 287, 41931-41938, http://dx.doi.org/10.1074/jbc.M112.418210.

133. Langereis, M.A.; van Vliet, A.L.W.; Boot, W.; de Groot, R.J. Attachment of Mouse Hepatitis Virus to OAcetylated Sialic Acid Is Mediated by Hemagglutinin-Esterase and Not by the Spike Protein. J Virol 2010, 84, 8970-8974, http://dx.doi.org/10.1128/JVI.00566-10. 